\title{
Chapter 9 \\ Microbial Agents in the Indoor \\ Environment: Associations with Health
}

\author{
Dan Norbäck and Gui-Hong Cai
}

\begin{abstract}
There is international consensus that damp buildings and indoor mould can increase the risk of asthma, rhinitis, bronchitis and respiratory tract infections but we do not know which types of microbial agents that are causing the observed adverse health effects. Microbial indoor exposure is a broader concept than microbial growth in buildings. Other sources of indoor microbial exposure include the outdoor environment, humans (crowdedness) and furry pet keeping. Microbial exposure can have different health effects depending on the dose, different exposure route, genetic disposition and the timing of exposure. Microbial stimulation linked to large microbial diversity in early life can protect against disease development, especially for allergic asthma and atopy. Protective effects are more often reported for bacterial exposure and adverse health effects are more often linked to mould exposure. There are many studies on health associations for indoor exposure to endotoxin, mainly from homes. The risk of getting atopic asthma may be less if you are exposed to endotoxin in childhood but the risk of non-atopic asthma may increase if exposed to endotoxin especially in adulthood. Moreover, genetic disposition modifies health effects of endotoxin. Epidemiological studies on muramic acid (from gram-positive bacteria) or ergosterol (from mould) are few. Studies on health effects of indoor exposure to beta-1-3-glucan (from mould) have conflicting results (positive as well as negative associations). Epidemiological studies on health effects of indoor exposure to mycotoxins are very few. Some studies have reported health associations for MVOC, but it is unclear to what extent MVOC has microbial sources in indoor environments. Many studies have reported health associations for fungal DNA, especially as a risk factor for childhood asthma at home. Since most studies on health effects of indoor exposure to mould, bacteria and microbial agents are cross-sectional, it is difficult to draw conclusions on causality. More prospective studies on indoor microbial exposure are needed and studies should include other indoor environments than homes, such as day care centers, schools, hospitals and offices.
\end{abstract}

D. Norbäck $(\bowtie) \cdot$ G.-H. Cai

Department of Medical Sciences, Uppsala University, Uppsala, Sweden

e-mail: dan.norback@medsci.uu.se 
Keywords Mould $\cdot$ Bacteria $\cdot$ Endotoxin $\cdot$ Beta-1-3-glucan $\cdot$ Muramic acid Fungal DNA $\cdot$ Microbial volatile organic compounds (MVOC) $\cdot$ Mycotoxins Asthma $\cdot$ Respiratory symptoms

\subsection{Introduction}

A large proportion of the total biomass in our planet consists of mould and bacteria. Thus it is not surprising that some of the microorganisms found in indoor environments have outdoor sources. Moreover, mould and bacteria can grow on damp surfaces or in water damaged building materials and spread to the indoor environment [1]. Moreover, free living amoeba can sometimes be found in indoor environments and survive on water damaged building materials [2]. Presence of humans is an important indoor source of bacteria, especially for gram-positive skin bacteria. Keeping cats and dog and crowdedness in indoor environments can increase the exposure to endotoxin, a microbial compound from gram-negative bacteria [3]. Moreover, there can be higher levels of mould in settled dust if the concentration of furry pet allergens is higher, suggesting a link between furry pet keeping and mould contamination [4]. Dust on indoor surfaces is an important reservoir of mould, bacteria and microbial compounds which can be re-suspended into the air when people are moving around in the buildings.

The World Health Organization (WHO) has concluded that damp buildings and mould can increase the risk of asthma, rhinitis, bronchitis and respiratory tract infections, but it is unclear which types of microbial agents that are causing the health effects [5]. Moisture and mould are common in homes. In the European Community Respiratory Health Survey (ECRHS), $24.8 \%$ of a random sample of adult population reported that they had observed indoor mould in the current home and $27.9 \%$ had water damage. Inspectors visiting the homes observed mould in $13.6 \%$ and moisture stains in $18.2 \%$ of the homes [6]. Microorganisms and microbial agents can be measured in building materials, on indoor surfaces, in indoor surface dust (settled particles) and in air samples. The measurements include a sampling procedure, sample preparation and detection and quantification of mould, bacteria or microbial compounds. One major problem with air sampling of mould and bacteria is the short sampling time (usually from minutes up to hours) and the large fluctuation of air concentrations of microorganisms over time in the same building.

Mould and bacteria can produce different types of microbial components such as cell-wall compounds (endotoxin, muramic acid, beta-1-3-glucan, ergosterol), allergenic proteins (fungal allergens), volatile organic compounds of microbial origin (MVOC) and microbial secondary metabolites (often called "mycotoxins") [1, 7]. A recent hot topic is the role of microbial diversity for human health. Epidemiological 
studies have demonstrated that exposure to high microbial diversity in early life can protect against the development of asthma and allergic disease [8]. Another recent topic is the importance of biological ultrafine particles in indoor dust containing fragments from bacteria [9] and fungal fragments [10]. Most health effects of indoor exposure to mould and bacteria are not linked to infections by pathogenic species. However, the legionella bacteria can be spread in indoor environments and cause lung inflammation (legionellosis) [11]. Aspergillus mould species can colonise the respiratory tract of immunosuppressed subjects and cause lung Aspergillosis [12]. Moreover, there can be indoor airborne transmission of virus and bacteria causing SARS, influenza, measles, tuberculosis and Middle East Respiratory Syndrome coronavirus infection (MERS) [13]. This book chapter will describe health associations for mould, bacteria and microbial agents in different indoor environments (Fig. 9.1 and Table 9.1).

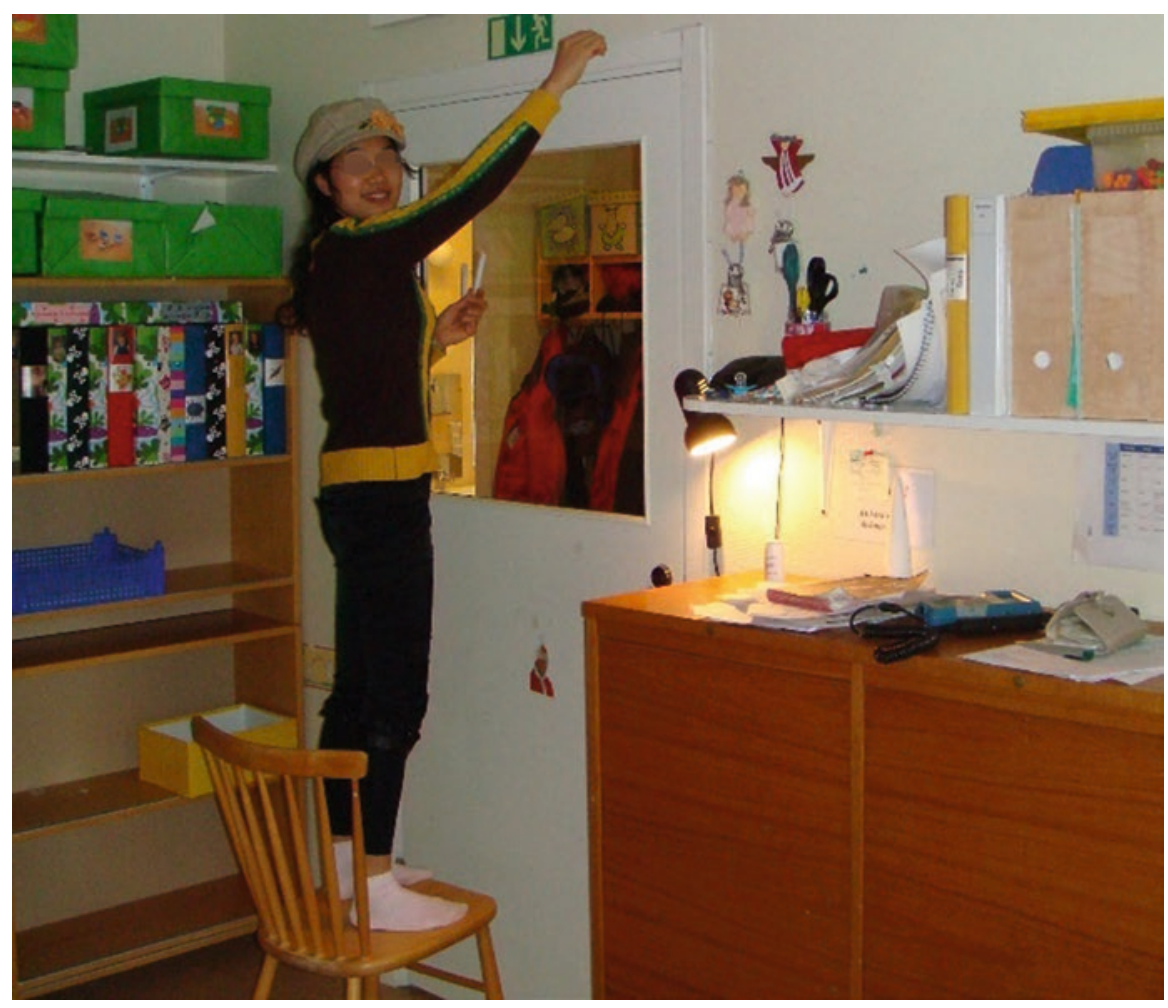

Fig. 9.1 Sampling of settled dust from a door frame in a day care center for analysis of fungal DNA 
Table 9.1 Examples of microbial agents found in microorganisms

Endotoxin: A cell-wall compound found in gram-negative bacteria (endotoxin can have different chain length of the 3-hydroxy acids in the molecule)

Muramic acid (MuA): A cell-wall compound found mainly in gram-positive bacteria

Ergosterol: A cell-wall compound found in mould (but also in plant materials)

Beta 1-3 glucans: A group of cell-wall compounds in mould (but also in pollen)t

Fungal DNA: DNA sequences specific for mould (general or species specific sequences)

Bacterial DNA: DNA sequences specific for bacteria (general or species specific sequences)

MVOC: Volatile organic compounds produced by microorganisms (but can have non-microbial sources as well)

Secondary microbial metabolites: Chemical compounds produced by the secondary metabolism of microorganisms

Mycotoxins: Chemical compounds with toxic properties produced by mould (a subgroup of secondary microbial metabolites)

\subsection{Viable Airborne Mould}

Viable airborne mould has been measured in indoor air for many decades but cultivation methods are more and more replaced by molecular methods. One major methodological limitation when measuring viable airborne mould is the large day to day variation of air concentrations [14]. Many samples must be taken in different seasons to get a reliable estimate of the long-term exposure. Most indoor mould are non-viable mould and can only be detected by DNA based molecular methods or counting methods. When using cultivation methods, Cladosporium, Alternaria, Aspergillus and Penicillium are dominating fungal genera in indoor air samples but when identifying indoor mould by metagenomic methods other species are dominating. As an example, Cladosporium, Alternaria, Aspergillus and Penicillium genera represented $<12 \%$ of the total DNA sequences found in dust from day care centers [15]. Some mould species are normally found indoors but may come mainly from the outdoor environment. Other moulds are typical for damp buildings. Fungal genera that may grow on damp building materials include: Acremonium, Aspergillus, Aureobasidium, Chaetomium, Chrysosporium, Cladosporium, Eurotium, Exophiala, Fusarium, Geomyces, Geotrichum, Monocillium, Mucor, Oidiodendrum, Paecilomyces, Penicillium, Phialophora, Phoma, Rhizopus, Scopulariopsis, Sphaeropsidales group, Stachybotrys, Trichoderma, Tritirachium, Ulocladium, Wallemia and yeasts [1]. Some mould species can contain allergenic proteins causing IgE mediated allergy. Cladosporium sp. and Alternaria sp. are important outdoor fungal allergens and Penicillium sp. and Aspergillus sp. are implicated in allergic diseases as indoor allergens. Malassezia $s p$. are associated with atopic dermatitis but not respiratory allergies [12]. One review of the epidemiological literature on health associations for different mould species concluded that Penicillium, Aspergillus, Cladosporium and Alternaria species pose a respiratory health risk for children and adults, including exacerbation of asthma [16]. Another review on indoor environmental exposure focused specifically on exacerbation of asthma [17]. 
They concluded that there is sufficient evidence of a causal association between outdoor culturable fungal exposure and exacerbation in asthmatics sensitised to fungi. They also concluded that there is limited or suggestive evidence of an association between indoor culturable Penicillium exposure and exacerbation in asthmatic children with specific sensitization, any fungal sensitization, or unspecific sensitization. Moreover they concluded that there is limited or suggestive evidence of an association between indoor total culturable fungal exposure and exacerbation of asthma in children with any fungal sensitisation [17]. Few studies exist on associations between sick building syndrome (SBS) symptoms and viable airborne mould. One study from newly built dwellings in Japan found that Rhodotorula $s p$. were associated with any SBS symptoms and Aspergillus $s p$. was associated with eye symptoms. In contrast, Eurotium $s p$. was negatively associated with skin symptoms (a protective effect) [18].

\subsection{Viable Airborne Bacteria}

Human beings is one main source of indoor bacteria, especially gram positive skin bacteria. Moreover, bacteria can grow on damp building materials [19] but few studies exist on viable airborne bacteria in relation to damp buildings. In building investigations in damp buildings in Sweden, the genera Bacillus, Pseudomonas and Streptomyces can often be detected in air samples and material samples [20, 21]. One study from day care centers in Turkey reported that Staphylococcus, Bacillus, Corynebacterium and Micrococcus were dominating genera in indoor air [22]. Another study from schools in Ethiopia reported that Staphylococcus aureus and coagulase-negative Staphylococcus species and Bacillus species were among the bacterial species in classroom air [23]. Actinobacteria is a large group of grampositive soil bacteria common in indoor environments. Some species of sporeforming filamentous actinomycetes have been associated with moisture damage and respiratory disorders [24]. Streptomyces $s p$. is one type of spore-forming actinomycetes, producing geosmin, a compound with strong soil odour [25]. Few studies exist on respiratory health associations for non-pathogenic viable airborne bacteria. A study in a water damaged office building found that thermophilic actinomycetes in vacuumed dust was associated with lower lung function $\left(\mathrm{FEV}_{1}\right)$ and nontuberculosis mycobacteria level was associated with asthmatic symptoms [26].

\subsection{Total Airborne Mould and Bacteria}

Since only a small proportion of indoor mould and bacteria are viable, there is a need for other methods detecting non-viable and non-culturable mould and bacteria in indoor air samples. Counting based methods have been used for many decades. They are based on staining of sampled mould and bacteria followed by counting in 
a microscope. Counting methods have limited measurement range, can be disturbed by other particles, are time consuming and need trained laboratory staff. Because of these limitations, they are nowadays replaced by molecular methods, e.g. quantitative PCR (QPCR) [27, 28]. The CAMNEA method (Collection of Airborne Microorganisms on Nucleopore filters, Estimation and Analysis) is an established counting method used to quantify total mould and total bacteria in air samples and material samples from damp buildings. It is based on staining with acridine orange followed by epifluorescence microscopy [29]. Some studies exist on respiratory health associations for total mould and bacteria by the CAMNEA method. One study from Sweden found higher levels of airborne total mould and total bacteria in home of asthmatic adults as compared to levels in homes of non-asthmatics [30]. In the European HESE study (Health Effects of the School Environment), a similar association was found between the concentration of airborne total mould and cough and rhinitis [31]. A prospective study among young adults in Australia found that increasing the total level of mould in air at home increased the risk of developing atopy [32]. A four-year prospective school study from Sweden found an association between total mould concentration in classroom air at baseline and new asthma diagnosis among school children [33]. Another Swedish school study found associations between total mould concentration in the classrooms and nasal mucosal swelling and increase of biomarkers of inflammation in nasal lavage from the teachers [20]. In contrast, the total bacteria concentration in air was negatively associated with nasal mucosal swelling and eosinophilic cationic protein (ECP) concentration in nasal lavage fluid (a protective effect) [20]. ECP is a marker of eosinophilic (allergic) inflammation.

\subsection{Endotoxin}

Bacteria are classified as gram-negative or gram-positive bacteria. The cell walls of all gram-negative bacteria contain lipopolysaccharide (LPS, endotoxin). Endotoxin is mostly measured by the biological limulus test [34] but 3-hydroxy fatty acid from endotoxin can also be measured by chemical analysis $[35,36]$ The chemical method can classify endotoxin into five different subgroups (C10, C12, C14, C16, C18) depending on the length of the 3-hydoxy fatty acids. Different species of gramnegative bacteria produce different length of the 3-hydroxy fatty acid. Katja Radon has summarised the health effects of endotoxin with respect to different types of asthma [34]. Endotoxin has immune stimulatory and proinflammatory properties even in small amounts linked to the CD14 molecule. Endotoxin can influence the innate immune system, trigger toll-like receptors (TLR-2 and TLR-4) and influence cytokine production. The connection between endotoxin exposure and respiratory disease and allergies has been investigated in many studies. The risk of getting atopic asthma may be less if you are exposed to endotoxin in childhood. However, the risk of non-atopic asthma may increase if exposed to endotoxin especially in adulthood [34]. One office study from the Netherlands reported an association 
between gram-negative bacteria and endotoxin concentrations in indoor air, measured by the limulus method, and sick building syndrome (SBS) [37]. SBS include eye nose, throat and dermal symptoms, headache and fatigue. A study among school children in Malaysia found different health associations for different types of endotoxin in classroom dust, measured by chemical analysis of 3-hydroxy fatty acids. Endotoxin with C14 3-hydroxy fatty acids was associated with rhinitis, C16 endotoxin was associated with dermal symptoms and C12 endotoxin was negatively associated with throat symptoms (a protective effect) [36]. Other studies on association between endotoxin and asthmatic symptoms, using chemical analysis of 3-hydroxy fatty acids, have demonstrated different health associations for different types of endotoxin $[35,38]$.

\subsection{Muramic Acid}

Peptidoglycan is present in all bacteria, but the largest amounts are found in grampositive bacteria. Muramic acid (MuA) is a chemical compound present in peptidoglycan and is a marker of gram-positive bacteria. Muramic acid can trigger toll-like receptors (TLR-2) in the immune system. Some epidemiological studies on health associations for MuA exist. In a birth cohort from Finland, the concentration of $\mathrm{MuA}$ in household dust was associated with asthma incidence in an inverted u-shape way. The highest risk was found at medium levels and the lowest risk at the highest levels [39]. Among school children in Austria, Switzerland and Germany, children with higher MuA concentration in mattress dust had lower prevalence of wheeze (a protective effect) [40]. In two school environment studies from China, MuA concentration in classroom dust was negatively associated with prevalence of asthmatic symptoms [38] and onset of mucosal symptoms (a protective effect) [41]. In the European Community Respiratory Health Survey (ECRHS) MuA concentration in mattress dust was positively associated with asthmatic symptom score [42] but a case-control study within the ECRHS study found a negative association between MuA and asthma [43].

\subsection{Ergosterol}

Ergosterol is a cell-wall compound found in all microfungi (mould) and macrofungi (mushrooms). However, ergosterol can be found in plant materials and is not entirely specific for mould. Some epidemiological studies on health associations for ergosterol exist. In a school study from Malaysia, ergosterol in classroom dust was a risk factor for doctors' diagnosed asthma [35] but a protective factor for rhinitis [36].

One study from USA in a water damaged office building found an association between levels of ergosterol in vacuumed dust and current asthma [44]. Another study from USA in two hospital buildings found associations between ergosterol 
levels in vacuumed dust and work-related asthmatic symptoms among hospital workers [45].

\subsection{Beta-1-3-Glucans}

Beta-1-3-glucans is a group of polysaccharide found in the cell-walls of mould. This compound can have different chain length and configuration. In 1995, the literature on health associations for beta-1-3-glucans was reviewed. It was concluded that available epidemiology does not permit conclusions on respiratory health associations for beta-1-3-glucans [46]. A more recent review on fungal exposure and asthma reported that mounting data supports the view that beta-1-3-glucans contributes to asthma development and severity but there are several studies that support that beta1-3-glucan is protective in asthma development. The review concluded that the conflicting results imply that beta-1-3-glucans may have different health effects depending on the dose, different exposure route and the timing of exposure [10].

\subsection{Fungal DNA}

Detection and quantification of various mould species can be done by molecular methods (PCR) that can measure DNA from different species of mould in dust or air, no matter whether they are dead or alive. The method is called mould specific quantitative PCR (MSQPCR) [47]. It can detect both general groups of mould and species-specific DNA sequences. In the last decades, epidemiological articles have been published on health association for fungal DNA, mainly on childhood asthma. Data on fungal DNA in indoor samples can be analysed in different ways. Studies have analysed health associations for the number of fungal DNA-sequences per gram vacuumed dust ("concentration in dust") or the number of fungal DNA sequences per surface area ("surface contamination").

One Swedish study found associations between the concentration of fungal DNA in dust from day care centers and fraction of exhaled nitric oxide (FeNO), highsensitivity C-reactive protein in blood (HsCRP) and dyspnea among day care center staff. Health associations were found for total fungal DNA and DNA from Aspergillus or Penicillium species and Aspergillus versicolor. The sequence "total fungal DNA" is a sequence common for many hundreds of mould species, but not for all mould. The authors concluded that in day care centers, DNA from some species of mould (Aspergillus sp., Penicillium sp. and Aspergillus versicolor) as well as the total load of mould (measured as total fungal DNA) can be risk factors for airway inflammation [48]. School studies in Europe, Malaysia and China have investigated associations between levels of fungal DNA in classroom dust and health among the school children [35, 36, 41, 49-52]. All school studies found associations between levels of fungal DNA in the classrooms and respiratory illness 
(elevated FeNO levels, asthmatic symptoms, respiratory infections or lower lung function) as well as SBS symptoms (ocular symptoms, rhinitis, tiredness). SBS symptoms include ocular, nasal throat and dermal symptoms, headache and fatigue [53]. Most consistent associations were found for Aspergillus versicolor DNA. Total fungal DNA was associated with respiratory illness in some, but not all studies. Some studies have investigated health association for fungal DNA in household dust. One case-control study reported that levels of Aspergillus versicolor DNA were higher in asthmatics homes as compared to controls [54]. Another study found that the DNA from the fungal genus Volutella was associated with increased asthma severity in atopic children [55].

Vesper et al. has developed a concept called Enviromental Relative Moldiness Index (ERMI) to quantify the mould burden in homes [56]. The ERMI value is computed from the concentrations of species specific DNA sequences from 36 indicator mould species in home dust samples. The mould species are divided in two groups. The first group (group 1 mould) consists of 26 mould species that indicate water damage (Table 9.2). The second group (group 2 mould) consist of sequences from ten Group 2 species that can be from outdoor sources and are commonly found indoors even without water damage [56] (Table 9.3). For each home, the mould burden is computed by taking the sum of log-transformed group 1 mould species concentrations minus the sum of log-transformed group 2 mould species concentrations. The ERMI value does not measure the total fungal concentration in the dust or the total fungal exposure. It is used to rank homes with respect to the relative mould burden in homes [57-59]. ERMI has been used in epidemiological studies and higher ERMI levels have been found in home dust among children with asthma as compared to controls without asthma [60-62]. One longitudinal study found that early exposure to molds as measured by ERMI at 1 year of age, but not 7 years of age, increased the risk for asthma at 7 years of age [63]. In addition, one recent

Table 9.2 Mould species included in the ERMI index

\begin{tabular}{l}
\hline Group 1 (26 species linked to dampness conditions causing indoor mould growth) \\
\hline Ten Aspergillus species: Aspergillus flavus; Aspergillus fumigatus; Aspergillus niger; \\
Aspergillus ochraceus; Aspergillus penicillioides; Aspergillus restrictus; Aspergillus \\
sclerotiorum, Aspergillus sydowii; Aspergillus unguis; Aspergillus versicolor \\
\hline Aureobasidium pullans \\
\hline Chaetomium globosum \\
\hline Cladosporium sphaerospermum \\
\hline Eurotium amstelodami \\
\hline Paecilomyces variotii \\
\hline Six Penicillium species: Penicillium brevicompactum; Penicillium corylophilum; Penicillium \\
group 2, Penicillium purpurogenum, Penicillium spinulosum, Penicillium variabile \\
\hline Scopulariopsis brevicaulis \\
\hline Scopulariopsis chartarum \\
\hline Stachybotrys chartarum \\
\hline Tricoderma viride \\
\hline Wallemia sebi
\end{tabular}


Table 9.3 Mould species included in the ERMI index

\begin{tabular}{l}
$\begin{array}{l}\text { Group } 2 \text { (ten species found in normal indoor } \\
\text { environments without dampness) }\end{array}$ \\
\hline Acremonium strictum \\
\hline Alternaria alternata \\
\hline Aspergillus ustus \\
\hline Cladosporium cladosporioides (Type 1) \\
\hline Cladosporium cladosporioides (Type 2) \\
\hline Cladosporium herbarum \\
\hline Epicoccum nigrum \\
\hline Mucor racemosus \\
\hline Penicillium chrysogenum (Type 2) \\
\hline Rhizopus stolonifer
\end{tabular}

study found higher ERMI values in school dust from schools with high prevalence of asthma as compared to schools with low asthma prevalence [64]. Finally, one study found lower lung function $\left(\mathrm{FEV}_{1}\right)$ among children who lived in homes with higher ERMI-values [65]. A recent study found associations between ERMI values and asthma and asthma and respiratory illness in two low-income Hispanic communities in California [66] A few studies exist on associations between ERMI values and adult asthma. One study from Scotland (UK) found lower lung function $\left(\mathrm{FEV}_{1}\right)$ among non-smoking adults living in homes with higher ERMI-values [67]. Another study from USA found an association between ERMI values in household dust and asthma and rhinitis among adults [68].

\subsection{Bacterial DNA}

Only few studies exist on associations between bacterial DNA in indoor environments and respiratory health. In one study from the ECRHS cohort, mattress dust from homes was extracted by gel electrophoresis and selected bands were sequenced by QPCR. The Clostridium cluster XI band was associated with a lower risk of prevalent adult asthma [69]. Another study among pre-school children in USA found a negative association between Streptomyces DNA concentration in household dust and FeNO in asthmatic children (a protective effect) but not in healthy children [70]. FeNO is a marker of allergic lower airway inflammation. One home environment study from USA investigated associations between indoor microbial community structure and concentration in household dust and asthma severity in atopic and non-atopic children. Increased bacterial richness was associated with increased asthma severity. Richness was based on number of operational taxonomic units among 2500 sequences per sample [55]. In a school environment study from Malaysia, Streptomyces DNA concentration in classroom dust was associated with more asthma [49] but less tiredness among school children [36]. In the European HESE school study, Streptomyces DNA concentration in classroom dust was associated with lower lung function $\left(\mathrm{FEV}_{1}\right.$ and $\left.\mathrm{FVC}\right)$ [31]. 


\subsection{Volatile Organic Compounds of Possible Microbial Origin (MVOC)}

Dampness can cause chemical degradation of building materials with chemical emissions and odour not linked to microbial growth. One example is emission of 2-ethyl-1-hexanol by alkaline degradation of a phthalate (DEHP; di-ethyl-hexyl phthalate) used as plasticiser in PVC floor materials. In addition, alkaline degradation of di-ethyl-hexyl acrylate in water-based floor can produce the same compound [71]. Chlorophenols, including pentachlorophenol (PCP), were commonly used as wood preservative in wooden houses until the 1980 'ies in many countries. In damp conditions, microbes can produce various chloroanisoles by dechlorination and methylation of PCP. Some chloroanisols have a strong mould odour [72]. The metabolism of mould and bacteria can produce certain volatile organic compounds (VOC) called microbial volatile organic compounds (MVOC) [73]. MVOCs can be produced by mould as well as bacteria. The production of MVOC can be influenced by the type of species but is mainly linked to environmental conditions and the material where the microorganisms grow. Some of these compounds have specific mould odour. The compound 1-octen-3-ol has a specific mushroom odour. The compound geosmin is produced by Streptomyces species and has a strong soil odour. MVOC includes alcohols (1-butanol; iso-butanol; 3-methyl-1-butanol; 2-methyl1-butanol; 2-methyl-1-propanol; 1-pentanol; 2-pentanol; 1-octen-3-ol; 3-octanol), ketones (2-hexanone, 2-heptanone, 2-octanone, 3-octanone; 6-methyl-5-heptene-2one), esters (isobutyl acetate; bornylacetate, isobornyl acetate, linalylacetate, butanoic acid, 3-methylbutyl-ester; ethyl-isobutyrate; ethyl-2-methylbutyrate), furans (2-methylfuran; 3-methylfuran; 2-pentylfuran), terpenes (beta-myrcene; verbenone; terpinolene; camphene; sabinene; alfa-phellandrene; beta-phellandrene; isoterpinolene; alfa-terpinene; gamma-terpinene; fenchone) and other compounds (camphor; estragol; dimethyl disulphide, geosmin) (Table 9.4).

In the 1990'ies, researchers in Sweden, Finland and Germany started to measure MVOCs in the indoor environment to detect hidden microbial growth in the construction [73-75]. The concentration of most MVOCs in the indoor environment is very low, typically ranging from $\mathrm{ng} / \mathrm{m}^{3}$ to $\mu \mathrm{g} / \mathrm{m}^{3}$ of air. One early study from Germany reported that MVOC levels were higher in homes with mould growth [76]. A study from homes in three North European cities found higher levels of

Table 9.4 Examples of MVOC compounds reported in the literature

Alcohols: 1-butanol; iso-butanol; 3-methyl-1-butanol; 2-methyl-1-butanol; 2-methyl-1propanol; 1-pentanol; 2-pentanol; 1-octen-3-ol; 3-octanol

Ketones: 2-hexanone, 2-heptanone, 2-octanone, 3-octanone; 6-methyl-5-heptene-2-one

Esters: isobutyl acetate; bornylacetate, isobornyl acetate, linalylacetate, butanoic acid, 3-methylbutyl-ester; ethyl-isobutyrate; ethyl-2-methylbutyrate

Furans: 2-methylfuran; 3-methylfuran; 2-pentylfuran

Terpenes: beta-myrcene; verbenone; terpinolene; camphene; sabinene; alfa-phellandrene; beta-phellandrene; isoterpinolene; alfa-terpinene; gamma-terpinene; fenchone

Other compounds: camphor; estragol; dimethyl disulphide, geosmin 
3-methylfuran and ethyl-isobutyrate in air in damp homes as compared to non-damp homes [77]. Later research has demonstrated that many MVOCs are not specific for microbial growth. One study compared air concentration of MVOCs in dwellings in Germany with and without indoor mould growth. Only 2-methyl-1-butanol and 1-octen-3-ol showed a significant association with mould status [78]. Another study measuring 28 MVOC compounds found that MVOCs are related to synthetic materials at home and to less extent related to microbial sources [79]. Even if some studies found significantly higher levels of some MVOC in damp and mouldy buildings as compared to normal buildings, the differences in MVOC concentrations are not large. One literature review on MVOC reported that more than 200 compounds have been identified as MVOCs in laboratory experiments but the recognition of microbially contaminated indoor environment by MVOC measurements has not been successful with current analytical methods [80]. Another methodological problem is that the indoor concentration of MVOCs is influenced by the ventilation flow, which means that it can be difficult to estimate if there is increased emission of MVOCs from the construction without taking into consideration the ventilation flow.

Some epidemiological studies have demonstrated associations between MVOC air concentrations in homes and health. In the German study, children in dwellings with elevated MVOC levels had a non-significant tendency of more asthma, hay fever, wheeze and eye irritation [76]. One study from France reported an association between a fungal index, based on MVOC measurements in the home, and current asthma and bronchitis [81]. One study from Japan found an association between 1-octen-3-ol concentrations in the home and allergic rhinitis and conjunctivitis [82]. Another article from the same Japanese study found an association between 1-octen3-ol and home-related mucous membrane symptoms [83]. One Swedish school study reported associations between total MVOC levels in the classrooms and nocturnal breathlessness and doctor diagnosed asthma among the school children. Wheeze was associated with 3-octanone, only. Doctor diagnosed asthma was associated with 2-heptanone and 2-methyl-1-butanol. Nocturnal attacks of breathlessness were associated with many types of MVOC (3-methylfuran, 3-methyl-1-butanol, dimethyldisulphide, 2-heptanone, 1-octen-3-ol, 3-octanone, 2-methyl-1-butanol, 2-penthylfuran, isobutylacetate and 1-butanol) [84]. In the home environment study in homes in three North European cities, there were positive associations between any SBS symptom and 2-pentanol, 2-hexaone, 2-pentylfuran, 1-octen-3-ol. Two compounds, 1-octen-3-ol and 3-methylfuran, were positively associated with mucosal SBS symptoms. Two compounds (ethyl isobutyrate and ethyl-2-methylbutyrate) were negatively associated with any SBS symptom (a protective effect) [77]. In the case-control study among pre-school children in Sweden by Choi et al., there was an association between sum concentration of 28 MVOC and case status, but only in homes with high absolute air humidity. The case definition among the pre-school children was based on wheeze, rhinitis or eczema [79]. In the literature review on MVOC, toxicological and exposure data was collected for 15 common MVOC. The most obvious health effects of MVOC exposure were eye and upper-airway irritation but the toxicological database was poor for these 15 compounds. The review suggested that there may be more potent compounds and other endpoint not yet evaluated [80]. 


\subsection{Mycotoxins}

Microorganisms can produce metabolites in their secondary metabolism, sometimes called microbial toxins. Mycotoxins are defined as toxic compounds produced by mould. Mycotoxins can grow in food and the main concern about human exposure is linked to food contamination. Aflatoxins (Aflatoxin B1, B2, G1, G2 and M1) are classified as human carcinogens (group 1) and the mycotoxins fumonisin B1, fumonisin B2, fusarin C, ochratoxin A and sterigmatocystin are classified as possible human carcinogens (group 2B) [85]. The classification of these mycotoxins as human carcinogens is based on dietary intake of contaminated food, not indoor exposure. Recent development of chemical analytical methods has made it possible to measure secondary microbial metabolites (and mycotoxins) in damp building materials and in indoor dust. The European HITEA school study (Health Effects of Indoor Pollutants: Integrating Microbial, Toxicological and Epidemiological Approaches) is one of the largest studies on exposure to secondary microbial metabolites in indoor environments [86]. Totally 30 secondary metabolites could be detected in 97 European schools, but the article did not include any health evaluation. The most common mycotoxins were emodin, physcion and the enniatins A1, B and B1. Less common mycotoxins were alamethicin, melagrin, griseofulvin, apicidin, beauvericin, trichodermol and verrucarol. About half of the school contained at least one secondary microbial metabolite. The levels were very low, typically $0.1-1$ picogram $/ \mathrm{m}^{2}$ of swabbed area. Schools with dampness or moisture damage contained higher levels of microbial secondary metabolites than non-damp schools [86].

The health significance of indoor exposure to fungal secondary metabolites (mycotoxins) remains unclear because of lack of epidemiological studies. One review article describes possible adverse health effects of indoor mould, including effects of mycotoxins [87]. Certain mycotoxins can have pronounced health effects in experimental animal studies or in vitro tests but it has been unclear if the exposure levels in indoor environments are enough to cause any health effects. One recent review article summarised available data on the low-molecular-weight toxins from fungi common in damp building materials, and exposure levels found in indoor environments. The review conclude that it is possible that toxin doses at levels found in damp buildings could modulate genes that are in the asthma pathways, but next decade of research will illuminate the significance of this information [88]. In the context of indoor mycotoxin exposure, there has been a special focus on trichothecene mycotoxins from the mould Stachybotrys chartarum [89]. However, existing epidemiology on association between mycotoxins in general, including mycotoxins from Stachybotrys chartarum, is sparse. One study from Finland measured 333 secondary metabolites in 99 homes of 1-year old children. A total of 44 different microbial metabolites were detected in the homes. The number of metabolites tended to be higher in homes with dampness and mould. However, the sum of microbial secondary metabolites was negatively associated with current asthma (a protective effect). The authors concluded that there were no evidence indicating that secondary microbial metabolite could explain the well-known association between indoor mould and dampness and asthma [90]. One school study from Malaysia measured mycotoxins 
and fungal DNA in classroom dust in 32 classrooms. Stachybotrys chartarum DNA was detected in $3 \%$ of the classrooms. Three types of mycotoxins were detected. Aflatoxin B1 was detected in 3\%, sterigmatocystin in 6\% and verrucarol in 12\% of the classrooms. Verrucarol is produced by Stachybotrys chartarum. There were negative associations between the mycotoxin verrucarol and Stachybotrys chartarum DNA levels on indoor surfaces and daytime attacks of breathlessness among school children (a protective effect) [49]. In contrast, there were positive associations in the study between verrucarol levels and Stachybotrys chartarum DNA levels in the classrooms and the prevalence of tiredness among the children [51].

\subsection{Conclusions and Recommendations}

Dampness and indoor microbial growth of mould and bacteria is common in indoor environments in many countries. There is international consensus, based on epidemiological evidence, that damp buildings and indoor mould can increase the risk of asthma, rhinitis, bronchitis and respiratory tract infections. However, there is not enough epidemiological studies to clarify which types of microbial agents that are causing the observed adverse health effects in damp buildings. Microbial indoor exposure is a broader concept than microbial growth in buildings. Other sources of indoor microbial exposure include air and dust from the outdoor environment, humans (crowdedness), furry pet keeping. Microbial exposure can have different health effects depending on the dose, different exposure route, genetic disposition and the timing of exposure. There is now epidemiological evidence that microbial stimulation linked to large microbial diversity in early life can protect against disease development, especially for allergic asthma and atopy. In epidemiological studies, protective effects are more often reported for bacterial exposure and adverse health effects are more linked to mould exposure. However, some studies have reported protective effects of mould and adverse effects of bacterial exposure.

There are many epidemiological studies on health associations for indoor exposure to endotoxin, mainly from the home environment. The risk of getting atopic asthma may be less if you are exposed to endotoxin in childhood but the risk of non-atopic asthma may increase if exposed to endotoxin especially in adulthood. Moreover, genetic disposition is an important factor influencing health effects of endotoxin exposure. Epidemiological studies reporting health associations (positively or negatively) with other cell-wall compounds such as muramic acid and ergosterol are few. Studies on health effects of indoor exposure to beta-1-3-glucan have found positive as well as negative health associations (conflicting results). Epidemiological studies on health effects of indoor exposure to mycotoxins are very few. Some epidemiological studies have reported health associations for MVOC, but it is unclear to what extent MVOC has microbial sources in indoor environments. There are an increasing number of studies reporting health associations for fungal DNA, especially adverse effects in relation to childhood asthma. Most of these studies have investigated fungal DNA in homes. Since most studies on health 
effects of indoor exposure to mould, bacteria and microbial compounds are crosssectional, it is difficult to draw conclusions on causality. More prospective studies on indoor microbial exposure are needed. Moreover, epidemiological studies on microbial exposure should include other indoor environments than homes, such as day care centers, schools, hospitals and offices.

\section{References}

1. Nevalainen A, Täubel M, Hyvärinen A. Indoor fungi: companions and contaminants. Indoor Air. 2015;25:1-32.

2. Yli-Pirilä T, Kusnetsov J, Hirvonen MR, Seuri M, Nevalainen A. Survival of amoebae on building materials. Indoor Air. 2009;19:113-21.

3. Chen CM, Thiering E, Doekes G, Zock JP, Bakolis I, Norbäck D, Sunyer D, Villani S, Verlato G, Täubel M, Jarvis D, Heinrich J. Geographic variation and the determinants of domestic endotoxin levels in mattress dust in Europe. Indoor Air. 2012;22:24-32.

4. Cai GH, Bröms K, Mälarstig B, Zhao ZH, Kim JL, Svärdsudd K, Janson C, Norbäck D. Quantitative PCR analysis of fungal DNA in Swedish day care centers and comparison with building characteristics and allergen levels. Indoor Air. 2009;19:392-400.

5. World Health Organization (WHO) Regional Office for Europe. Guidelines for indoor air quality: dampness and mould. Copenhagen: WHO Regional Office for Europe; 2009. p. 1-228.

6. Norbäck D, Zock JP, Plana E, Heinrich J, Svanes C, Sunyer J, Künzli N, Villani S, Olivieri M, Soon A, Jarvis D. Mould and dampness in dwelling places, and onset of asthma: the population-based cohort ECRHS. Occup Environ Med. 2013;70:325-31.

7. Tischer CG, Heinrich J. Exposure assessment of residential mold, fungi and microbial components in relation to children's health: achievements and challenges. Int J Hyg Environ Health. 2013;216:109-14.

8. von Mutius E. The microbial environment and its influence on asthma prevention in early life. J Allergy Clin Immunol. 2016;137:680-9.

9. Yang J, Kim YK, Kang TS, Jee YK, Kim YY. Importance of indoor dust biological ultrafine particles in the pathogenesis of chronic inflammatory lung diseases. Environ Health Toxicol. 2017;32:e2017021.

10. Zhang Z, Reponen T, Hershey GK. Fungal exposure and asthma: IgE and non-IgE-mediated mechanisms. Curr Allergy Asthma Rep. 2016;16:86.

11. van Kenhove E, Dinne K, Janssens A, Laverge J. Overview and comparison of legionella regulations worldwide. Am J Infect Control. 2019; https://doi.org/10.1016/j.ajic.2018.10.006.

12. Fukutomi Y, Taniguchi M. Sensitization to fungal allergens: resolved and unresolved issues. Allergol Int. 2015;64:321-31.

13. Luongo JC, Fennelly KP, Keen JA, Zhai ZJ, Jones BVV, Miller SL. Role of mechanical ventilation in the airborne transmission of infectious agents in buildings. Indoor Air. 2016;26:666-78.

14. Verhoeff SP, van Wijnen JGH, Fischer P, Brunekreef B, Boleij JS, van Reenen ES, Samson RA. Presence of viable mould propagules in the indoor air of houses. Toxicol Ind Health. 1990;6:133-45.

15. Shin SK, Kim J, Ha SM, Oh HS, Chun J, Sohn J, Yi H. Metagenomic insights into the bioaerosols in the indoor and outdoor environments of childcare facilities. PLoS One. 2015;10:e126960.

16. Sharpe RA, Bearman N, Thornton CR, Husk K, Osborne NJ. Indoor fungal diversity and asthma. A meta-analysis and systematic review of risk factors. J Allergy Clin Immunol. 2015;135:110-22.

17. Kanchongkittiphon W, Mendell MJ, Gaffin JM, Wang G, Phipatanakul W. Indoor environmental exposures and exacerbation of asthma: an update to the 2000 review by the Institute of Medicine. Environ Health Perspect. 2015;123:6-20. 
18. Saijo Y, Kanazawa A, Araki A, Morimoto K, Nakayama K, Takigawa T, Tanaka M, Shibata E, Yoshimura T, Chjikara H, Kishi R. Relationships between mite allergen levels, mold concentrations, and sick building syndrome symptoms in newly built dwellings in Japan. Indoor Air. 2011;21:253-63.

19. Fujiyoshi S, Tanaka D, Maruyama F. Transmission of airborne bacteria across built environments and its measurement standards: a review. Front Microbiol. 2017;8:2336.

20. Norbäck D, Wålinder R, Wieslander G, Smedje G, Erwall C, Venge P. Indoor air pollutants in schools: nasal patency and biomarkers in nasal lavage. Allergy. 2000;55:163-70.

21. Walinder R, Norbäck D, Wessen B, Venge P. Nasal lavage biomarkers: effects of water damage and microbial growth in an office building. Arch Environ Health. 2001;56:30-6.

22. Aydogdu H, Asan A, Tatman OM. Indoor and outdoor airborne bacteria in child day-care centers in Edirne City (Turkey), seasonal distribution and influence of meteorological factors. Environ Monit Assess. 2010;164:53-66.

23. Andualem Z, Gizaw Z, Bogale L, Dagne H. Indoor bacterial load and its correlation to physical indoor air quality parameters in public primary schools. Multidicip Respir Med. 2019;14(1):2.

24. Rintala H. Actinobacteria in indoor environments: exposures and respiratory health effects. Front Biosci (School Ed). 2011;3:1273-84.

25. Johansson E, Vesper S, Levin L, LeMasters G, Grinshpun S, Reponen T. Streptomycetes in house dust: associations with housing characteristics and endotoxin. Indoor Air. 2011;21:300-10.

26. Park JH, Cox-Ganser JM, White SK, Laney AS, Caulfield SM, Turner WA, Sumner AD, Kreiss $\mathrm{K}$. Bacteria in a water-damaged building: associations of actinomycetes and non-tuberculosis mycobacteria with respiratory health in occupants. Indoor Air. 2017;27:24-33.

27. Meheust D, Le Cann P, Reboux G, Millon L, Gangneux JP. Indoor fungal contamination: health risks and measurement methods in hospitals, homes and workplaces. Crit Rev Microbiol. 2014;40:248-60.

28. Norbäck D, Cai GH. Dampness, indoor mould, fungal DNA and respiratory health-molecular methods in indoor epidemiology. Clin Exp Allergy. 2015;45:840-3.

29. Palmgren U, Ström G, Blomqvist G, Malmberg P. Collection of airborne micro-organisms on Nucleopore filter, estimation and analysis-CAMNEA method. J Appl Bacteriol. 1986;61:401-6.

30. Björnsson E, Norbäck D, Janson C, Widström HJ, Palmgren U, Ström G, Boman G. Asthmatic symptoms and indoor levels of micro-organisms and house dust mites. Clin Exp Allergy. 1995;25:423-31.

31. Simoni M, Cai GH, Norback D, Annesi-Maesano I, Lavaud F, Sigsgaard T, Wieslander G, Nystad W, Canciani M, Viegi G, Sestini P. Total viable moulds and fungal DNA in classrooms and associations with respiratory health and pulmonary function of European schoolchildren. Pediatr Allergy Immunol. 2011;22:843-52.

32. Matheson MC, Abrahamson MJ, Dharmage SC, Forbes AB, Raven JM, Thien FC, Walters $\mathrm{EH}$. Changes in indoor allergen and fungal levels predicts changes in asthma activity among young adults. Clin Exp Allergy. 2005;35:907-13.

33. Smedje G, Norbäck D. Incidence of asthma diagnosis and self-reported allergy in relation to the school environment- a four-year follow-up study in schoolchildren. Int J Tuberc Lung Dis. 2001;5:1059-66.

34. Radon K. The two sides of the "endotoxin coin". Occup Environ Med. 2006;63:73-8.

35. Norbäck D, Markowicz P, Cai GH, Hashim Z, Ali F, Zheng YW, Lai XX, Spangfort MD, Larsson L, Hashim JH. Endotoxin, ergosterol, fungal DNA and allergens in dust from schools in Johor Bahru, Malaysia-associations with asthma and respiratory infections in pupils. PLoS One. 2014;9:e883303.

36. Norbäck D, Hashim JH, Markowicz P, Cai GH, Hashim Z, Ali F, Larsson L. Endotoxin, ergosterol, muramic acid and fungal DNA in dust from schools in Johor Bahru, Malaysia - associations with rhinitis and sick building syndrome (SBS) in junior high school students. Sci Total Environ. 2016;545-546:95-103. 
37. Teeuw KB, Vandenbroucke-Grauls CM, Verhoeff J. Airborne gram-negative bacteria and endotoxin in sick building syndrome. A study in Dutch governmental office buildings. Arch Intern Med. 1994;154:2339-45.

38. Zhao Z, Sebastian A, Larsson L, Wang Z, Zhang Z, Norbäck D. Asthmatic symptoms among pupils in relation to microbial dust exposure in schools in Taiyuan, China. Pediatr Allergy Immunol. 2008;19:455-65.

39. Karvonen AM, Hyvärinen A, Rintala H, Korppi M, Täubel M, Doekes G, Gehring U, Renz H, Pfefferle PI, Genuneit J, Keski-Nisula L, Remes S, Lampi J, von Mutius E, Pekkanen J. Quantity and diversity of environmental microbial exposure and development of asthma: a birth cohort study. Allergy. 2014;69:1092-101.

40. van Strien RT, Engel R, Holst O, Bufe A, Eder W, Waser M, Braun-Fahrländer C, Riedler J, Nowak D, von Mutius E, Study Team ALEX. Microbial exposure of rural school children, as assessed by levels of $\mathrm{N}$-acetyl-muramic acid in mattress dust, and its association with respiratory health. J Allergy Clin Immunol. 2004;113:860-7.

41. Zhang X, Zhao Z, Nordqvist T, Larsson L, Sebastian A, Norbäck D. A longitudinal study of sick building syndrome among pupils in relation to microbial components in dust in schools in China. Sci Total Environ. 2011;409:5253-9.

42. Tischer C, Zock JP, Valkonen M, Doekes G, Guerra S, Heederik D, Jarvis D, Norbäck D, Olivieri M, Sunyer J, Svanes C, Täubel M, Thiering G, Verlato G, Hyvärinen A, Heinrich J. Predictors of microbial agents in dust and respiratory health in the Ecrhs. BMC Pulm Med. 2015;15:48.

43. Valkonen M, Täubel M, Pekkanen J, Tischer C, Rintala H, Zock JP, Casas L, Probst-Hensch N, Forsberg B, Holm M, Janson C, Pin I, Gislason T, Jarvis D, Heinrich J, Hyvärinen A. Microbial characteristics in homes of asthmatic and non-asthmatic adults in the ECRHS cohort. Indoor Air. 2018;28:16-27.

44. Park JH, Cox-Ganser JM, Kreiss SK, White SK, Rao CY. Hydrophilic fungi and ergosterol associated with respiratory illness in a water-damaged building. Environ Health Perspect. 2008; $116: 45-50$.

45. Cox-Ganser JM, Rao CY, Park JH, Schumpert JC, Kreiss K. Asthma and respiratory symptoms in hospital workers related to dampness and biological contaminants. Indoor Air. 2009;19:280-90.

46. Douwes J. (1 $\rightarrow 3)$-Beta-D-glucans and respiratory health: a review of the scientific evidence. Indoor Air. 2005;15:160-9.

47. Vesper SJ, Wymer LJ, Meklin T, Varma M, Stott R, Richardson M, et al. Comparison of populations of mould species in homes in the UK and USA using mould-specific quantitative PCR (MSQPCR). Lett Appl Microbiol. 2005;41:367-73.

48. Norback D, Cai GH, Kreft I, Lampa E, Wieslander G. Fungal DNA in dust in Swedish day care centres: associations with respiratory symptoms, fractional exhaled nitric oxide (FeNO) and C-reactive protein (CRP) in serum among day care Centre staff. Int Arch Occup Environ Health. 2016;89:331-40.

49. Cai GH, Jamal HH, Hashim Z, Ali F, Bloom E, Larsson L, Lampa E, Norbäck D. Fungal DNA, allergens, mycotoxins and associations with asthmatic symptoms among pupils in schools in Johor Bahru, Malaysia. Pediatr Allergy Immunol. 2011;22:290-7.

50. Norbäck D, Hashim JH, Hashim Z, Cai G-H, Sooria V, Ismail SA, Wieslander G. Respiratory symptoms and fractional exhaled nitric oxide (FeNO) among students in Penang, Malaysia in relation to signs of dampness at school and fungal DNA in school dust. Sci Total Environ. 2017;577:148-54.

51. Norbäck D, Hashim JH, Cai GH, Hashim Z, Ali F, Bloom E, Larsson L. Rhinitis, throat and dermal symptoms, headache and tiredness among students in schools from Johor Bahru, Malaysia: Associations with fungal DNA and mycotoxins in classroom dust. PLoS One. 2016;11:e1479976. 
52. Norbäck D, Hashim JH, Hashim Z, Sooria V, Ismail MS, Wieslander G. Ocular symptoms and tear film break up time (BUT) among junior high school students in Penang, Malaysia- associations with fungal DNA in school dust. Int J Hyg Environ Health. 2017;220:697-703.

53. Norbäck D. An update on sick building syndrome. Curr Opin Allergy Clin Immunol. 2009;9:55-9.

54. Bellanger AP, Reboux G, Roussel S, Grenouillet F, Didier-Scherer E, Dalphin JC, Millon L. Indoor fungal contamination of moisture-damaged and allergic patient housing analyzed using real-time PCR. Lett Appl Microbiol. 2009;49:260-6.

55. Dannemiller KC, Gent JF, Leaderer BP, Peccia J. Indoor microbial communities: influence on asthma severity in atopic and noatopic children. J Allergy Clin Immunol. 2016;138:76-83.

56. Vesper S, McKinstry C, Haugland R, Wymer L, Bradham K, Ashley P, Cox D, Dewalt G, Friedman W. Development of an environmental relative moldiness index for US homes. J Occup Environ Med. 2007;49:829-33.

57. Vesper S, McKinstry C, Cox D, Dewalt G. Correlation between ERMI values and other moisture and Mold assessments of homes in the American healthy homes survey. J Urban Health. 2009;86:850-60.

58. Vesper S, McKinstry C, Bradham K, Ashley P, Cox D, Dewalt G, Lin KT. Screening tools to estimate mold burdens in homes. J Occup Environ Med. 2009;51:80-6.

59. Vesper S, Wakefield J, Ashley P, Cox D, Dewalt G, Friedman W. Geographic distribution of environmental relative moldiness index molds in USA homes. J Environ Public Health. 2011;2011:242457.

60. Vesper SJ, McKinstry C, Ashley P, Haugland RA, Yeatts K, Bradham K, Svendsen E. Quantitative PCR analysis of molds in the dust from homes of asthmatic children in North Carolina. J Environ Monit. 2007;9:826-30.

61. Vesper SJ, McKinstry C, Haugland R, Neas L, Hudgens E, Heidenfelder B, Gallagher J. Higher environmental relative moldiness index (ERMIsm) values measured in Detroit homes of severely asthmatic children. Sci Total Environ. 2008;394:192-6.

62. Vesper S, Barnes C, Ciaccio CE, Johanns A, Kennedy K, Murphy JS, Nunez-Alvarez A, Sandel MT, Cox D, Dewalt G, Ashley PJ. Higher environmental relative moldiness index (ERMI) values measured in homes of asthmatic children in Boston, Kansas City, and San Diego. J Asthma. 2013;50:155-61.

63. Reponen T, Vesper S, Levin L, Johansson E, Ryan P, Burkle J, Grinshpun SA, Zheng S, Bernstein DI, Lockey J, Villareal M, Khurana Hersehy GK, LeMastrers G. High environmental relative moldiness index during infancy as a predictor of asthma at 7 years of age. Ann Allergy Asthma Immunol. 2011;107:120-6.

64. Vesper S, Prill R, Wymer L, Adkins L, Williams R, Fulk F. Mold contamination in schools with either high or low prevalence of asthma. Pediatr Allergy Immunol. 2015;26:49-53.

65. Vesper SJ, Wymer L, Kennedy S, Grimsey LF. Decreased pulmonary function measured in children exposed to high environmental relative moldiness index homes. Open Respir Med J. 2013;7:83-6.

66. Sinclair R, Russell C, Kray G, Vesper S. Asthma risk associated with indoor mold contamination in hispanic communities in eastern Cochella valley, California. J Environ Public Health. 2018;2018:9350370.

67. McSharry C, Vesper S, Wymer L, Howieson S, Chaudhuri R, Wright GR, Thomson NC. Decreased FEV1\% in asthmatic adults in Scottish homes with high environmental relative moldiness index values. Clin Exp Allergy. 2015;45:902-7.

68. Blanc PD, Quinlan PJ, Katz PP, Balmes JR, Trupin L, Cisternas MG, Wymer L, Vesper SJ. Higher environmental relative moldiness index values measured in homes of adults with asthma, rhinitis or both conditions. Environ Res. 2013;122:98-101.

69. Pekkanen J, Valkonen M, Täubel M, Tischer C, Leppänen H, Kärkkäinen PM, Rintala H, Zock JP, Casas L, Probst-Hensch N, Forsberg B, Holm M, Janson C, Pin I, Gislason T, Jarvis 
D, Heinrich J, Hyvärinen A. Indoor bacteria and asthma in adults: a multicenter case-control study within ECRHSII. Eur Respir J. 2018;51(2):1701241.

70. Johansson E, Reponen T, Vesper S, Levin L, Lockey J, Ryan P, Bernstein DI, Villareal M, Khurana Hershey GK, Schaffer C, Lemasters G. Microbial content of household dust associated with exhaled NO in asthmatic children. Environ Int. 2013;59:141-7.

71. Wieslander G, Kumlin A, Norbäck D. Dampness and 2-ethyl-1-hexanol in floor construction of rehabilitation center: health effects in staff. Arch Environ Occup Health. 2010;65:3-11.

72. Lorentzen JC, Juran SA, Nilsson M, Nordin S, Johanson G. Chloroanisoles may explain mold odor and represent a major indoor environment problem in Sweden. Indoor Air. 2016;26:207-18.

73. Wessen B, Schoeps KO. Microbial volatile organic compounds-what substances can be found in sick buildings? Analyst. 1996;121:1203-5.

74. Korpi A, Kasanen JP, Alaire Y, Kosma VM, Pasanen AL. Sensory irritation potency of some microbial volatile organic compounds (MVOCs) and a mixture of five MVOCs. Arch Envion Health. 1999;54:347-52.

75. Fisher G, Dott W. Relevance of airborne fungi and their secondary metabolites for environmental, occupational and indoor hygiene. Arch Microbiol. 2003;179:75-82.

76. Elke K, Begerow J, Oppermann H, Krämer U, Jermann E, Dunemann L. Determination of selected microbial volatile organic compounds by diffusion sampling and dual-column capillary GC-FID- a new feasible approach for the detection of an exposure to indoor mould fungi? J Environ Monit. 1999;1:455-2.

77. Sahlberg B, Gunnbjörnsdottir M, Soon A, Jogi R, Gislason T, Wieslander G, Janson C, Norback D. Airborne molds and bacteria, microbial volatile organic compounds (MVOC), plasticizers and formaldehyde in dwellings in three north European cities in relation to sick building syndrome (SBS). Sci Total Environ. 2013;444:433-40.

78. Schleibinger H, Laussmann D, Bornehag CG, Eis D, Rueden H. Microbial volatile organic compounds in the air of moldy and mold-free environments. Indoor Air. 2008;18:113-24.

79. Choi H, Schmidbauer N, Bornehag CG. Non-microbial sources of microbial volatile organic compounds. Environ Res. 2016;148:127-36.

80. Korpi A, Järnberg J, Pasanen AL. Microbial volatile organic compounds. Crit Rev Toxicol. 2008;39:139-93.

81. Hulin M, Moularat S, Kirschner S, Robine E, Mandin C, Annesi-Maesano I. Positive associations between respiratory outcomes and fungal index in rural inhabitants of a representative sample of French dwellings. Int J Hyg Environ Health. 2013;216:155-62.

82. Araki A, Kanazawa A, Kawai T, Eitaki Y, Morimoto K, Nakayama K, Shibata K, Tanaka M, Takigawa T, Yoshimura T, Chikara H, Saijo Y, Kishi R. The relationship between exposure to microbial volatile organic compound and allergy prevalence in single-family homes. Sci Total Environ. 2012;423:18-26.

83. Araki A, Kawai T, Eitaki Y, Kanazawa A, Morimoto K, Nakayama K, Shibata K, Tanaka M, Takigawa T, Yoshimura T, Chikara H, Saijo Y, Kishi R. Relationship between selected indoor volatile organic compounds, so called microbial VOC, and the prevalence of mucous membrane symptoms in single family homes. Sci Total Environ. 2010;408:228-2215.

84. Kim JL, Elfman L, Mi Y, Wieslander G, Smedje G, Norbäck D. Indoor molds, bacteria, microbial volatile organic compounds and plasticizers in schools-associations with asthma and respiratory symptoms in pupils. Indoor Air. 2007;17:153-63.

85. Ostry V, Malir F, Toman J, Grosse Y. Mycotoxins as human carcinogens-the IARC monographs classification. Mycotoxin Res. 2017;33:65-73.

86. Peitzsch M, Sulyok M, Täubel M, Vishwanath V, Krop E, Borras-Santos A, Hyvärinen A, Nevalainen A, Krska R, Larsson L. Microbial secondary metabolites in school buildings inspected for moisture damage in Finland, The Netherlands and Spain. J Environ Monit. 2012;14:2044-53. 
87. Pieckova E. Adverse health effects of indoor molds. Arh Hig Rada Tokiskol. 2012;63:545-9.

88. Miller JD, McMullin DR. Fungal secondary metabolites as harmful indoor air contaminants: 10 years on. Appl Microbiol Biotechnol. 2014;98:9953-66.

89. Pestka JJ, Yike I, Dearborn DG, Ward MD, Harkema JR. Stachybotrys chartarum, trichothecene mycotoxins, and damp building-related illness: new insights into a public enigma. Toxicol Sci. 2018;104:4-26.

90. Kirjavainen PV, Täubel M, Karvonen AM, Sulyok M, Tittanen P, Krska R, Hyvärinen A, Pekkanen J. Microbial secondary metabolites in homes in association with moisture damage and asthma. Indoor Air. 2016;26:448-4576. 